Diabetologia 7, 156-159(1971)

(C) by Springer-Verlag 1971

\title{
Diurnal Variation of Oral Glucose Tolerance in Volunteers and Laboratory Animals
}

\author{
R. BeN-Dyke \\ Department of Toxicology, Fisons Ltd. Agrochemical Division, Chesterford Park Research Station, Saffron Walden, \\ Essex, England
}

Received: November 13, 1970, accepted: March 26, 1971

\begin{abstract}
Summary. Studies of the oral glucose tolerance test performed at $0900 \mathrm{~h}$ and $1400 \mathrm{~h}$ have shown a diurnal variation of glucose tolerance in normal rabbits and rats. Similar variable responses in a small series of volunteers have also been demonstrated. Carbohydrate-intolerant animals differ from the normal animals studied in that no morning and afternoon variation of response to a constant oral glucose challeng'e has been observed.
\end{abstract}

Variation diume de la tolérance au glucose oral chez des volontaires et des animaux de laboratoire

Résumé. Des études du test de tolérance au glucose oral, effectué à $9 \mathrm{~h}$ et à $14 \mathrm{~h}$ ont montré une variation diurne de la tolérance au glucose chez des lapins et des rats normaux. On a également constaté des réponses variables similaires chez un petit nombre de volontaires. Les animaux intolérants aux hydrates de carbone, diffèrent des animaux normaux par le fait que l'on n'observe pas chez eux de variation diurne de la réponse à une charge orale constante en glucose.

Tageszeitliche Verönderungen der oralen Glucosetoleranz bei freiwilligen Versuchspersonen und Laboratoriumstieren

Zusammenfassung. Untersuchungen der oralen Glucose-Toleranz, die um $9 \mathrm{~h}$ und $14 \mathrm{~h}$ durchgeführt wurden, zeigten eine von der Tageszeit abhängige Variation bei normalen Kaninchen und Ratten. Bei einer kleinen Anzahl von freiwilligen Versuchspersonen ließen sich ähnliche Unterschiede feststellen. Tiere, die intolerant gegenüber Kohlenhydraten waren, unterschieden sich von nor. malen Tieren dadurch, daß bei Belastungen am Morgen und am Nachmittag keine Differenzen bei konstanter oraler Glucosebelastung zu beobachten waren.

Key-words: Glucose tolerance, diurnal, diabetes, animal, epidemiology.

\section{Indroduction}

The use of the oral glucose tolerance test as an aid to diagnosis of diabetes mellitus is an established procedure and has traditionally been carried out during morning clinics, although afternoon clinies are not uncommon. With the advent of population surveys glucose tolerance tests may be carried out at other times during the day dependent on subject availability and laboratory overload. Previously variation of glucose tolerance with time of the day has been reported $[1,9]$, although these results were not confirmed by others [3].

We have investigated the validity of extending the criteria of normality [3], according to which the level of blood glucose is below $120 \mathrm{mg} / 100 \mathrm{ml} 2 \mathrm{~h}$ after a $50 \mathrm{~g}$ oral glucose load and does not rise above $180 \mathrm{mg} / 100 \mathrm{ml}$, to glucose tolerance tests carried out in the afternoon. The purpose of the investigation was to elaborate on previous work and to examine the use of laboratory animals for studying the variation of glucose tolerance with time of the day.

\section{Methods}

Rabbits and rats from our animal colony were given a $0.75 \mathrm{~g} / \mathrm{kg}$ glucose load after an overnight fast, and the fasting and $2 \mathrm{~h}$ blood glucose after the load were measured. Where the blood glucose at $2 \mathrm{~h}$ was greater than $160 \mathrm{mg} / 100 \mathrm{ml}$ the animals were classed as carbohydrate intolerant. Values below this figure were regarded as normal for the purposes of the pre-experimental classification. After this initial investigation of glucose tolerance, 49 rabbits (weight $1.5-2.6 \mathrm{~kg}$ ) and 164 rats (weight $120-310 \mathrm{~g}$ ) with normal glucose tolerance, and 3 rabbits (weight $2.2-2.6 \mathrm{~kg}$ ) and 6 rats (weight 250-340 g) with abnormal glucose tolerance were taken from our animal colony and maintained on a normal diet for the period of the experiment, except for the $8 \mathrm{~h}$ preceding the test when they were given water ad libitum but no food. The glucose was ad. ministered at $0900 \mathrm{~h}$ or $1400 \mathrm{~h}$ as a $150 \mathrm{mg} / \mathrm{ml}$ solution at $5 \mathrm{ml} / \mathrm{kg}$ by gavage after removal of blood for determination of fasting blood glucose concentration. Further blood samples were withdrawn at $1 / 2$-hourly intervals up to and including $2 \mathrm{~h}$. Blood glucose concentrations were measured using the glucose oxidase/peroxidase o-dianisidine method [5]. Protein was precipitated from $10 \mu \mathrm{l}$ whole blood with $180 \mu \mathrm{l}$ zine sulphate/sodium sulphate and $10 \mu 1 \mathrm{~N} / 2$ sodium hydroxide. After centrifugation $100 \mu$ l of the supernatant was added to $5 \mathrm{ml}$ of the combined enzyme-chromogen reagent of Boehringer test kits.

14 healthy human volunteers were also investigated, the constitution of this group being 7 males aged $19-$ 38 , weight $67-73 \mathrm{~kg}$, height $1.72-1.83 \mathrm{~m}$, and 7 females aged $17-38$; weight $45-73 \mathrm{~kg}$, height $1.50-$ $1.68 \mathrm{~m} .50 \mathrm{~g}$ glucose loads in $250 \mathrm{ml}$ aqueous solution 
were given to these volunteers by mouth either at $0900 \mathrm{~h}$ or $1400 \mathrm{~h}$ on separate days. In all cases the volunteers fasted overnight prior to the morning test or for $8 \mathrm{~h}$ following a light breakfast for the afternoon test.

The results from all the experiments have been classified in 3 categories based on the blood glucose concentration:

Normal carbohy- No blood glucose level above drate tolerance $180 \mathrm{mg} / 100 \mathrm{ml}$ and the $2 \mathrm{~h}$ level below $110 \mathrm{mg} / 100 \mathrm{ml}$.

Borderline carbohydrate intolerance Any blood glucose level above $180 \mathrm{mg} / 100 \mathrm{ml}$ and/or $2 \mathrm{~h}$ level above $110 \mathrm{mg} / 100 \mathrm{ml}$ but below $160 \mathrm{mg} / 100 \mathrm{ml}$.

Carbohydrate $\quad 2 \mathrm{~h}$ blood glucose level above intolerant $\quad 160 \mathrm{mg} / 100 \mathrm{ml}$.

All results have been based on the mean of duplicate tests; where a statistical comparison of results has been carried out the chi-squared test of significance has been applied. animals. In rabbits the afternoon increase in the number of carbohydrate intolerant animals was also 4 -fold. Significant morning-afternoon differences existed between the numbers of rabbits classified as normal, borderline carbohydrate intolerant or carbohydrate intolerant. Although the number of volunteers was not sufficient to draw conclusions, they did show the same trend, an apparently higher incidence of carbohydrate intolerance in the afternoon, as was shown in the two animal populations studied.

Sub-division of the animals tested on the basis of the pre-experimental classification of normal or carbohydrate intolerant and comparison between the morning and afternoon results from the carbohydrate intolerant animals shows little difference. Treating the species separately there were insufficient abnormal animals for adequate statistical evaluation. Since the glucose load had been weight-adjusted and the response was similar in carbohydrate-intolerant rabbits and rats, the mean blood glucose levels from all these animals have been compared. The results show no

Table 1. Distribution of types of glucose tolerance test found in all subjects, comparing morning tests with afternoon tests (All results are the means of duplicate tests at both times on the same animal)

\begin{tabular}{|c|c|c|c|c|c|c|}
\hline Species & $\begin{array}{l}\text { Normal carb } \\
\text { tolerance } \\
\text { Number of } \\
\text { subjects } \\
\text { tested }\end{array}$ & $\begin{array}{l}\text { ohydrate } \\
\text { Percentage } \\
\text { of subjects } \\
\text { tested }\end{array}$ & $\begin{array}{l}\text { Borderline } \\
\text { intolerance } \\
\text { Number of } \\
\text { subjects } \\
\text { tested }\end{array}$ & $\begin{array}{l}\text { carbohydrate } \\
\text { Percentage } \\
\text { of subjects } \\
\text { tested }\end{array}$ & $\begin{array}{l}\text { Number of } \\
\text { subjects } \\
\text { tested }\end{array}$ & $\begin{array}{l}\text { te intolerant } \\
\text { Percentage } \\
\text { of subjects } \\
\text { tested }\end{array}$ \\
\hline $\begin{array}{l}\text { Rabbits } \\
\text { Morning } \\
\text { Afternoon }\end{array}$ & $\begin{array}{l}44 \\
22\end{array}$ & $\begin{array}{l}84.6 \\
42.3\end{array}$ & $\begin{array}{r}5 \\
20\end{array}$ & $\begin{array}{r}9.6 \\
38.5\end{array}$ & $\begin{array}{r}3 \\
10\end{array}$ & $\begin{array}{r}5.8 \\
19.2\end{array}$ \\
\hline Probability & & $<0.01$ & & $<0.01$ & & $<0.01$ \\
\hline $\begin{array}{l}\text { Rats } \\
\text { Morning } \\
\text { Afternoon }\end{array}$ & $\begin{array}{r}150 \\
83\end{array}$ & $\begin{array}{l}88.2 \\
48.8\end{array}$ & $\begin{array}{l}14 \\
57\end{array}$ & $\begin{array}{r}8.2 \\
33.5\end{array}$ & $\begin{array}{r}6 \\
30\end{array}$ & $\begin{array}{r}3.6 \\
17.7\end{array}$ \\
\hline Probability & & $<0.01$ & & $<0.01$ & & $<0.01$ \\
\hline $\begin{array}{l}\text { Human } \\
\text { Morning } \\
\text { Afternoon }\end{array}$ & $\begin{array}{r}13 \\
7\end{array}$ & $\begin{array}{l}92.9 \\
50.0\end{array}$ & $\begin{array}{l}1 \\
6\end{array}$ & $\begin{array}{r}7.1 \\
42.9\end{array}$ & $\begin{array}{l}0 \\
1\end{array}$ & $\begin{array}{l}0 \\
7.1\end{array}$ \\
\hline
\end{tabular}

\section{Results}

All animals and volunteers, regardless of their preexperimental blood glucose levels, have been classified on the basis of the levels after a glucose load, according to the criteria defined in the methods section. The results of the morning and afternoon tests in the same populations are presented in Table 1. The afternoon results in rats show a 4 -fold increase in the number of carbohydrate intolerant rats above the number found in the morning. The morning-afternoon differences in the number of animals in the three groups were significantly different for normal, borderline carbohydrate intolerant and carbohydrate intolerant groups of difference $(P>0.05)$ between the morning and afternoon blood glucose levels.

The mean blood glucose levels $( \pm 1$ SD) during the morning and afternoon $2 \mathrm{~h}$ periods of the tests are presented in Table 2 . The results have been sub-divided according to species and the pre-experimental classification of normal or abnormal glucose tolerance as defined in the methods section. In normal animals the afternoon fasting and $30 \mathrm{~min}$ blood glucose levels were similar to those found in the morning tests. The levels at 60,90 and $120 \mathrm{~min}$ were elevated in the afternoon, the greatest morning-afternoon difference being at $90 \mathrm{~min}$ in the rat and $60 \mathrm{~min}$ in the rabbit. The differences between the morning and afternoon results were 
statistically significant $(P<0.01)$ within the group with normal glucose tolerance at 60,90 and $120 \mathrm{~min}$ after the glucose load.

\section{Discussion}

Both Roberts [9] and Bowen and Reeves [1] have reported morning and afternoon differences of response to an oral glucose load in people at $60 \mathrm{~min}$ after the glucose load, although the results of Roberts [9] show a less significant difference at $120 \mathrm{~min}$ after the glucose load than those of Bowen and Reeves [1]. Our results in animals are similar to those of Bowen and Reeves [1] in that statistically significant morning and afternoon differences were demonstrated at 60,90 and 120 min after the glucose load. The results obtained using in animals and confirmed in humans by Jarrett and Keen $[6,7]$ would be to alter statistics regarding the incidence of diabetes in the population and, more important, to classify some subjects as diabetics who, if tested in the morning, would be classed as normal. It would be of considerable value if results of glucose tolerance tests included the time of day when the test was carried out to enable subsequent analysis of trends towards decreased glucose tolerance. The present results, showing differences between morning and afternoon glucose tolerance tests, make it seem possible that the criteria of normality [3] might be readjusted for use where the tests are carried out in the afternoon to enable a more direct comparison of results obtained at various times of the day.

In view of the fact that not all those who had normal tolerance curves in the morning had abnormal

Table 2. Morning-afternoon differences of mean ( $\pm S D$ ) blood glucose in some subgroups of the samples

\begin{tabular}{|c|c|c|c|c|c|}
\hline & \multirow{3}{*}{$\begin{array}{l}\text { Time } \\
\text { after } \\
\text { load } \\
\text { (Minutes) }\end{array}$} & \multicolumn{4}{|c|}{ Pre-experimental Classification } \\
\hline & & \multicolumn{2}{|l|}{ Normal } & \multicolumn{2}{|c|}{ Carbohydrate Intolerant } \\
\hline & & Morning & Afternoon & Morning & Afternoon \\
\hline Rats & $\begin{array}{r}0 \\
30 \\
60 \\
90 \\
120\end{array}$ & $\begin{array}{r}83( \pm 8.6) \\
158( \pm 19.4) \\
136( \pm 19.1) \\
113( \pm 16.1) \\
95( \pm 9.9)\end{array}$ & $\begin{array}{l}83( \pm 12.4) \\
158( \pm 20.2) \\
171( \pm 20.2)^{* *} \\
152( \pm 18.3)^{* *} \\
131( \pm 13.2)^{* *}\end{array}$ & $\begin{array}{l}131( \pm 9.3) \\
167( \pm 10.3) \\
228( \pm 14.6) \\
228( \pm 19.7) \\
200( \pm 19.0)\end{array}$ & $\begin{array}{l}134( \pm 10.2) \\
162( \pm 9.1) \\
243( \pm 17.3) \\
224( \pm 20.2) \\
204( \pm 16.3)\end{array}$ \\
\hline Rabbits & $\begin{array}{r}0 \\
30 \\
60 \\
90 \\
120\end{array}$ & $\begin{array}{r}69( \pm 9.2) \\
139( \pm 9.8) \\
125( \pm 14.6) \\
106( \pm 9.7 \\
95( \pm 10.3)\end{array}$ & $\begin{array}{l}76( \pm 14.3) \\
138( \pm 11.2) \\
175( \pm 20.4)^{* *} \\
132( \pm 18.2)^{*} \\
124( \pm 16.1)^{* *}\end{array}$ & $\begin{array}{l}122 \\
155 \\
240 \\
228 \\
203\end{array}$ & $\begin{array}{l}129 \\
156 \\
237 \\
226 \\
199\end{array}$ \\
\hline Human & $\begin{array}{r}0 \\
30 \\
60 \\
90 \\
120\end{array}$ & $\begin{array}{r}89( \pm 8.4) \\
140( \pm 14.6) \\
117( \pm 22.7) \\
102( \pm 25.9) \\
90( \pm 17.8)\end{array}$ & $\begin{array}{l}86( \pm 8.5) \\
133( \pm 16.6) \\
157( \pm 26.4) \\
128( \pm 16.1)^{* *} \\
110( \pm 16.6)^{*}\end{array}$ & $\begin{array}{l}- \\
- \\
- \\
-\end{array}$ & $\begin{array}{l}- \\
- \\
- \\
-\end{array}$ \\
\hline
\end{tabular}

the carbohydrate intolerant rabbits and rats reported here are similar to those of Roberts [9], who used some diabetic patients in his series, in that no significant morning-afternoon differences of glucose tolerance were demonstrated. The reason for this inability of the carbohydrate intolerant subject to exhibit a diurnal variation of glucose tolerance may be due to impaired pancreatic function and inability to vary insulin secretion.

Population surveys such as that carried out in Bedford $[10,2,8]$ are becoming more common. The tendency to perform oral glucose tolerance tests at variable times throughout the day, both on the initial survery and during subsequent "follow-up" sessions, has similarly increased. In such work, the effect of the morningafternoon variation of glucose tolerance demonstrated tolerance curves in the afternoon, it seems likely that those who are normal in the morning and not in the afternoon may contain a higher proportion of potentially chemical diabetics than would seem otherwise. An additional advantage of testing both in the morning and in the afternoon is that the afternoon test yields higher blood glucose levels and therefore the lower limit of abnormal suggested by our results is possibly a more tangible and obvious criterion of abnormality than those currently in use.

Experimental investigations of the reasons for the differences of glucose tolerance between the morning and the afternoon could be carried out in rabbits and rats, since it appears from the present investigation that similar differences are observed in these animals and in man. 


\section{References}

1. Bowen, A.J., Reeves, R.L.: Diurnal variation in glucose tolerance. Arch. intern. Med. 119, 261-264 (1967).

2. Butterfield, W.H.: Summary of results of Bedford diabetes survey. Proc. R. Soc. Med. 57, 196-200 (1964).

3. Fitzgerald, M.G., Keen, H.: Diagnostic classification of diabetes. Lancet 1964 I, $1325-1326$.

4. Hayner, N.S., Kjelsberg, M.O., Epstein, F.H., Francis, J., Jr.: Carbohydrate tolerance and diabetes in a total community, Tecumseh, Michigan. I. Effects of age, sex and test conditions on $1 \mathrm{~h}$ glucose tolerance in adults. Diabetes 14, 413-423 (1965).

5. Huggett, A.St.G., Nixon, D.A.: Use of glucose oxidase, peroxidase and o-dianisidine in the determination of blood and urinary glucose. Lancet 1957 II, $368-369$.
6. Jarrett, R.J., Keen, H.: Diurnal variation of oral glucose tolerance: a possible pointer to the evolution of diabetes mellitus. Brit. Med. J. 1969 II, $341-344$.

7. - - Further observations on the diurnal variation in oral glucose. Brit. Med. J. (in press).

8. Keen, H.: The Bedford survey: a critique of methods and findings. Proc. roy. Soc. Med. 57, 200-202 (1964).

9. Roberts, H.J.: Afternoon glucose tolerance testing: a key to the pathogenesis, early diagnosis and prognosis of diabetogenic hyperinsulinism. J. Amer. Geriat. Soc. 12, $423-472$ (1964).

10. Sharpe, C.R.: Diabetes survey in Bedford 1962. Proc. roy. Soc. Med. 57, 193-195 (1964).

Dr. R. Ben-Dyke

Dept. of Toxicology

Fisons Ltd. Agrochemical Division

Chesterford Park Research Station

Saffron Walden, Essex, England. 